\title{
Fitness, PA, Perceived Competence, Parental Support, and Literacy Outcomes in the REACH After-School Sports Program
}

\author{
Risto Marttinen ${ }^{1}$, Kelsey L. McAlister ${ }^{2}$, Samantha T. Ives ${ }^{1}$, Silvia Battistella ${ }^{1}$, Ray N. Fredrick III ${ }^{3}$, \\ Kelly Johnston ${ }^{4}$, Kathleen S. Wilson ${ }^{5}$ \\ ${ }^{1}$ George Mason University, Virginia, United States of America \\ ${ }^{2}$ University of Southern California, Los Angeles, United States of America \\ ${ }^{3}$ United States Military Academy at West Point, West Point, United States of America \\ ${ }^{4}$ Baylor University, Waco, United States of America \\ ${ }^{5}$ California State University, Fullerton, United States of America
}

\begin{abstract}
A B S T R A C T
The purpose of this study was to assess the effectiveness of the REACH program in increasing physical activity (PA) levels, cardiorespiratory fitness, perceived competence, self-efficacy, parental support, and literacy across a year-long after-school PA intervention. Two intervention and one control school $(N=78$ students) were recruited to collect data across two time points. School differences in post-intervention scores were found in three (parental support, literacy, PACER) of seven intervention-related measures. Parental support and PACER scores were higher in intervention schools. Results demonstrate that data collection methods need to be reconsidered in diverse low-income schools. A data collection dilemma is presented: researchers need data to understand what is happening but how are students being served by the data collection process? New approaches in low-income urban after-school programs need to be considered to limit loss of data and to make the data collection meaningful to student participants.
\end{abstract}

Key words: FITNESSGRAM, Latino/a, low-income title I, youth development

\section{Introduction}

After-school programs aim to provide safe childcare for students. This safety comes at a cost as billions of dollars are being spent on approximately 50,000 public after-school programs across the United States ${ }^{1}$. These programs aim to alleviate crime rates, academic achievement gaps, substance use, and a number of other behavioral problems, especially in high-risk populations ${ }^{2,3-4}$. Youth from low socioeconomic status (SES) and youth of racial and ethnic minority backgrounds are traditionally referred to as high-risk in the literature ${ }^{5}$. Although previous literature demonstrates that these high-risk populations would benefit most from after-school programs, a number of barriers including cost, availability, and safe travel keep these families from participating ${ }^{5,6}$.

Previous literature also shows that low participation in moderate-to-vigorous physical activity (PA) is associated with several sociodemographic characteristics. Basch ${ }^{7}$ found that rates of moderate-to-vigorous PA were lower in Black and Hispanic youth compared to White, with these variations especially evident in female youth. Other evidence supports that adolescent youth (ages 13 to 18 years) of higher SES are more active than youth of lower SES ${ }^{8}$. When comparing the amount of sitting time, Broderson et al. ${ }^{9}$ found that youth from lower SES families participated in sedentary behavior more so than youth from higher SES families. This same study also found that Black youth participated in more sedentary behavior than White youth ${ }^{9}$. School-based PA opportunities, including after-school programs that support PA, may be an important intervention for these underserved populations seeing that PA is substantially lower and sedentary behavior is higher in these groups. The after-school space is an ideal venue to provide opportunities for students to be physically active in structured and less-structured ways.

Increasing PA is particularly important due to the relationship between PA and academic achievement. After-school programs can be a great source of increased PA opportunities and can be a part of a comprehensive pro-

Received for publication July 27, 2021 
gram across the school ${ }^{7}$. One study found that students who added an hour a day of Physical Education to the standard one time a week Physical Education course had better academic performance than students who only participated in the standard, once a week Physical Education course $^{10}$. A more recent study by Coe and colleagues ${ }^{11}$ found a significant relationship between academic achievement and self-reported vigorous activity in sixth-grade youth. A systematic review by Rasberry and colleagues ${ }^{12}$ found that over $50 \%$ of 50 peer-reviewed studies found positive associations between PA and academic performance. This systematic review also found that 11 out of 14 school-based Physical Education programs resulted in positive associations between Physical Education and cognitive skills and attitudes, academic behavior, and academic achievement ${ }^{12}$. Although studies consistently show that an increase of PA during the school day has positive correlations with academic achievement, less is known about specific literacy outcomes.

Perceived competence has previously been found as an important correlate of PA in youth, with studies finding that perceived competence is associated with PA participation ${ }^{13,14-15}$. A longitudinal study by Barnett et al ${ }^{16}$ found that positive perception of sports competence is a key predictor of not only PA outcomes, but also fitness outcomes in youth. On the other hand, evidence indicates that parental support is also an important correlate of PA. A number of studies corroborate that parental support is significantly associated with child PA levels ${ }^{17}$. A more recent systematic review found strong associations between parental encouragement/support for PA and parents' own PA with their childs' PA level ${ }^{18}$. However, perceived competence and parental support in relation to PA participation are understudied in minority populations in low-socioeconomic schools. Furthermore, little is known about these factors in out of school physical activity settings.

The current study implemented a PA intervention with an overall goal to attempt to increase PA, fitness levels, and literacy of youth in low income communities. Additionally, we wanted to see if various factors changed as a result of participation in the REACH program, such as perceived competence. The REACH program (Reflective Educational Approach to Character and Health) is a 28week after-school program that was implemented in two low-income schools, using a third as a control, over an academic school year. The purpose of this study was to assess the effectiveness of the REACH program in increasing PA levels, fitness, perceived competence, self-efficacy, parental support, parental influence for PA, and literacy across a year-long after-school PA intervention.

\section{Methods}

\section{Participants}

Seventy-eight fifth and sixth grade students were recruited for this study from three, low-SES, Title I elemen- tary schools in southern California. Selected sampling was used and each school was non-randomly assigned to either one of the two interventions (REACH-Riverfront or REACH-Wesley) or the control (CON-Ravine) school. All school names are pseudonyms. The REACH school(s) were selected based off the nature of the demographics of the school being an underserved population and pre-existing relationships with the school district's after-school program. The control school was selected because it matched the demographics of the REACH schools (high population of Latino/a students), had similar after-school opportunities, and was closest to the area (2 miles away from the $\mathrm{REACH}$ schools) to ensure the youth represented similar neighborhoods.

Students from the REACH schools were recruited to attend an after-school program through parent informational sessions held during an open house at held at each of the schools. Further recruitment occurred with students were recommended to the REACH program by the after-school teacher/coordinator and by student peers. Once students were recruited to participate in $\mathrm{REACH}$, participants were then recruited to participate in the research study. Researchers explained the study aims and procedures to the REACH participants using a standardized script. A parent letter and an informed consent form were sent home with REACH participants interested in participating in the study. REACH participants who did not obtain parental consent and/or did not provide assent to participate were excluded from the study but were still allowed to participate in the REACH program activities, only two students fit these criteria and thus were excluded from the study. Students from the control school were recruited through communication with the school district and with the assistance of the school site lead.

\section{Ethics}

The Institutional Review Board of the university and the cooperating school district approved this study. Conversations about ethics arose about keeping a program from participants who may possibly benefit from its implementation. An agreement was made with the REACH-Wesley school to establish the REACH program at the school following a year of initial data collection in the 2016-2017 school year ${ }^{19}$. During the second year (2017-2018) of data collection of this two-year project the REACH program was established at both Wesley and Riverfront schools. Due to limited staffing, we were not able to offer programming at the control school (Control-Ravine) in the second year and a similar agreement was discussed to establish REACH at Ravine in the future. This study is presenting findings from this second year of the program only.

\section{Setting}

Both REACH intervention schools are classified as Title I and qualify for supplemental government funding due to the high percentage of students from low-income families. During the 2017-2018 school year, 734 (71.9\% Free 
or Reduced Lunch; 55\% English language learner's) students from the REACH-Riverfront school and 399 (68.9\% Free or Reduced Lunch; 57.1\% ELL's) students from REACH-Wesley school were enrolled. In the CON-Ravine school, 528 (50.5\% Free or Reduced Lunches; 36.7\% ELL's) students were enrolled. Combined, these three schools reported a total of 17 homeless students attending their schools. The schools were majority Latino/a with Wesley (87\%), Riverfront (86.9\%) and Ravine (75.9\%). No data were provided by the schools regarding the number of students with special needs.

\section{The REACH program}

The REACH program is an after-school approach to Physical Education in an urban context. The program was implemented in four 7-week sessions over an academic year and consisted of ninety-minute sessions occurring biweekly. Sessions were completed back to back in the Fall 2017 for a total of 14 weeks of programming, and then again during the Spring 2018 with back to back 7-week sessions totaling 28 weeks of programming. REACH focused on incorporating PA, literacy, and mental skills development as a way to empower students to challenge stereotypes, practice conflict resolution, and learn life skills that can extend outside of the program. REACH utilized sports as an avenue to promote PA by creating an environment for youth to develop an interest in and passion for being active.

The overarching goal of REACH is to provide youth in underserved communities a safe space for PA and learning experiences through a student-centered curriculum. The specific aims of the program are to (a) engage students in literacy practices through reflective and embodied activities, (b) teach students fitness and nutrition concepts they can incorporate into their daily lives to promote a healthy lifestyle, and (c) promote positive youth development through sport. Sessions are taught by pre-service physical education teachers (PST) who are under the supervision of a teacher educator and physical education researcher. Sessions are voluntary for students to attend and most PSTs are volunteering their time to teach the sessions. For further information on the REACH program and development see ${ }^{20}$. The curriculum focused on both PA and literacy development, both of which were delivered through a constant focus on character.

\section{Sports and $P A$}

The program's curriculum was divided into four major team sports (soccer, basketball, ultimate frisbee, and flag football). Additionally, students had the opportunity to choose other alternative activities they wanted to participate after learning the basics of the skills of the sports. Alternative activities included, dance, jump rope, non-traditional games and sports as well as fitness activities using resistance bands, and other fitness equipment.

\section{Literacy}

Additionally, each session consisted of a literacy component that included student-centered reading and writing activities. These activities built on some of the exemplary approaches Spielberger and Halpern ${ }^{21}$ identified in their multiple case study analysis of effective practices for fostering literacy development in after-school programs serving low-income communities. Further, these activities supported students' literacy development that aligned with Common Core State Standards. Wednesdays were reading days in which students independently read a self-selected book and then gathered into small groups to discuss their books with guided questions revolving around the theme or word of the week. This was modeled after a "book-club" style discussion. Fridays focused on reflective writing; students chose three questions out of a list of 100 possible questions. These questions ranged from topics on how they experienced life in school that week to health and fitness. Students were encouraged to answer in grammatically proper sentences with correct spelling in standard English.

\section{Procedures}

This study gathered information on PA, cardiorespiratory endurance, perceived competence, PA self-efficacy, perceived parental support for PA, and literacy from students who agreed to participate in the REACH program as well as a control group. Data were collected at several time-points across the 2017-2018 academic year: Baseline, Time 2, and Time 3. However, only baseline (before REACH programming started in August-September 2017) and Time 3 (a post-test at the conclusion of the program in May 2018) were used due to significant amounts of missing data during Time 2 (see Table 1). This will be discussed in detail within the discussion section. Additionally, demographic information such as, age, race, gender and grade were collected from students. Data were collected by a trained research staff and identical methods were used at each school. Data were collected during the same week of the month at each site.

\section{Instrumentation}

\section{Physical Activity for Children Questionnaire (PAQ-C)}

Children's participation in PA was measured using the Physical Activity Questionnaire for children (PAQ-C) ${ }^{22}$. The PAQ-C is a 9-item self-administered 7-day recall instrument. The questionnaire was administered at the beginning of the study and at the end. Both times students were asked to recall their participation in physical activities over the past 7 days and a summary PA score was derived from the mean of the nine items, each scored on a 5-point Likert scale.

\section{Cardiorespiratory fitness}

The PACER test was utilized to measure cardiorespiratory fitness levels in youth. Plowman ${ }^{23}$ has found the 
TABLE 1

FREQUENCY OF VALID AND MISSING DATA BY SCHOOL AND ACROSS TIME

\begin{tabular}{|c|c|c|c|c|c|c|c|c|c|c|}
\hline & & \multicolumn{3}{|c|}{ Baseline (pre) } & \multicolumn{3}{|c|}{ Time 2} & \multicolumn{3}{|c|}{ Time 3 (post) } \\
\hline & & Valid & Mis. & \% Mis. & Valid & Mis. & $\%$ Mis. & Valid & Mis. & $\%$ Mis. \\
\hline \multirow[t]{4}{*}{ PACER } & Ravine & 15 & 8 & 34.78 & - & - & - & 16 & 7 & 30.43 \\
\hline & Riverfront & 27 & 5 & 15.63 & 22 & 10 & 31.25 & 19 & 13 & 40.63 \\
\hline & Wesley & 19 & 4 & 17.39 & 18 & 5 & 21.74 & 12 & 11 & 47.83 \\
\hline & Total & 61 & 17 & 21.79 & 40 & 38 & 48.75 & 47 & 31 & 39.74 \\
\hline \multirow[t]{4}{*}{ PAQ-C } & Ravine & 7 & 16 & 69.57 & 1 & 22 & 95.65 & 13 & 10 & 43.48 \\
\hline & Riverfront & 27 & 5 & 15.63 & 25 & 7 & 21.88 & 18 & 14 & 43.75 \\
\hline & Wesley & 21 & 2 & 8.70 & 16 & 7 & 30.43 & 14 & 9 & 39.13 \\
\hline & Total & 55 & 23 & 29.49 & 42 & 36 & 46.15 & 45 & 33 & 42.31 \\
\hline \multirow[t]{4}{*}{ PASES } & Ravine & 7 & 16 & 69.57 & 1 & 22 & 95.65 & 13 & 10 & 43.48 \\
\hline & Riverfront & 29 & 3 & 9.38 & 25 & 7 & 21.88 & 18 & 14 & 43.75 \\
\hline & Wesley & 19 & 4 & 17.39 & 18 & 5 & 21.74 & 14 & 9 & 39.13 \\
\hline & Total & 55 & 23 & 29.49 & 44 & 34 & 43.59 & 45 & 33 & 42.31 \\
\hline \multirow{4}{*}{$\begin{array}{l}\text { Perceived } \\
\text { Compe- } \\
\text { tence } \\
\text { Scale }\end{array}$} & Ravine & 14 & 9 & 39.13 & - & - & - & 18 & 5 & 21.74 \\
\hline & Riverfront & 29 & 3 & 9.38 & - & - & - & 23 & 9 & 28.13 \\
\hline & Wesley & 21 & 2 & 8.70 & - & - & - & 14 & 9 & 39.13 \\
\hline & Total & 64 & 14 & 17.95 & - & - & - & 55 & 23 & 29.49 \\
\hline \multirow{4}{*}{$\begin{array}{l}\text { Parental } \\
\text { Support }\end{array}$} & Ravine & 7 & 16 & 69.57 & 1 & 22 & 95.65 & 13 & 10 & 43.48 \\
\hline & Riverfront & 29 & 3 & 9.38 & 25 & 7 & 21.88 & 18 & 14 & 43.75 \\
\hline & Wesley & 21 & 2 & 8.70 & - & - & - & 14 & 9 & 39.13 \\
\hline & Total & 57 & 21 & 26.92 & 26 & 52 & 66.67 & 45 & 33 & 42.31 \\
\hline \multirow[t]{4}{*}{ Lit } & Ravine & 8 & 15 & 65.22 & - & - & - & 11 & 12 & 52.17 \\
\hline & Riverfront & 15 & 17 & 53.13 & - & - & - & 16 & 16 & 50.00 \\
\hline & Wesley & 21 & 2 & 8.70 & - & - & - & 14 & 9 & 39.13 \\
\hline & Total & 44 & 34 & 43.59 & - & - & - & 41 & 37 & 47.44 \\
\hline
\end{tabular}

PACER test to be a valid and reliable tool to measure youth cardiorespiratory fitness levels.

\section{Physical activity Self-Efficacy Scale}

Children's level of self-efficacy for engaging in PA was assessed using a re-adaptation of the Physical Activity Self-Efficacy scale (PASES ${ }^{24}$ ) The revised scale consists of eight items shown to provide valid and reliable results in a sample of Caucasian and Hispanic children ${ }^{24}$. Each item was scored on a 3-point Likert-type scale with three possible answer choices with a value from 0 to 2 : "No" (0), "Not Sure" (1), and "Yes" (2). A mean score for was calculated to reflect the child's self-efficacy.

\section{Harter's perceived competence scale}

Self-esteem and self-concept in children were evaluated using select subscales from the Harter's perceived competence scale $e^{25}$. Scholastic competence, athletic competence and physical appearance questions were used in this study. The scoring protocols outlined in the manual were followed for each of the subscales ${ }^{26}$.

\section{Parental support for PA}

The parental support for PA scale viewed from the children point of view, was measured using a revised version of the five-item parental social support scale ${ }^{27}$. The ques- 
tionnaire assessed the weekly frequency with which parents encourage and help their child do PA or play sports. Responses were collected on a five-point scale ranging from none (1) to daily (5) and a mean score was calculated.

\section{Literacy}

While the Common Core State Standards include reading, writing, listening, and speaking as components of literacy, instrumentation only focused on traditional reading skills. Reading was evaluated by a pre and posttest ${ }^{28}$ that was given first in August-September of 2017 to both $5^{\text {th }}$ and $6^{\text {th }}$ grade students in the REACH (Wesley and Riverfront) and CON (Ravine) schools. These tests were provided through tablets where children were able to type in their responses to the questions and read the questions from the tablet. Questions were repeated for the posttest in May 2018 in the exact same fashion. During the time of testing, students sat quietly at tables and worked on the test until they completed it or one hour had elapsed at which time tests were collected. Pre and posttests were scored using a scoring guide by a professor with expertise in childhood literacy. Test data are presented in number of questions attempted, number correct, and differences from pre and posttest.

\section{Data analysis}

In order to determine differences in student outcomes between study sites (i.e., Riverfront, Wesley, or Ravine), we ran a series of one-way between subject ANCOVAs. The school was entered as the independent variable due to the potential differences occurring at the school level between the two intervention schools. In each ANCOVA we used the respective pre-intervention score as the covariate. To identify which schools' scores were statistically different, any significant ANCOVA was followed up with up with $t$ tests with a Bonferroni correction. We examined assumptions of normality, linearity, homogeneity of variance, and homogeneity of regression before performing the ANCOVAs.

The analyses used data only from participants who had both time 1 (pre-intervention) and time 3 (post-intervention) scores. The analyses focused on time 1 and time 3 because there were too many missing values for the time points in between (times 2). Due to the nature of data collection, there were many instances of missing data. See Table 1 for detailed information about missing data. For the control site, Ravine, missing data were imputed by series mean. We examined the data for outliers, resulting in four cases being removed from the analysis.

\section{Results}

\section{Participants}

There were 32 participants from Riverfront, 23 participants from Wesley, and 23 participants from Ravine. Participants (44.9\% female) represented an approximately even distribution of fifth grade $(42.3 \%)$ and sixth grade (41.0\%) students). See Table 2 for participant sociodemographic information. In some results the $N$ is lower due to the fact that some students did not complete the instru-

TABLE 2

PARTICIPANT SOCIODEMOGRAPHIC CHARACTERISTICS

\begin{tabular}{|c|c|c|c|c|c|c|c|c|}
\hline \multirow[t]{2}{*}{ Characteristic } & \multicolumn{2}{|c|}{ Riverfront } & \multicolumn{2}{|c|}{ Wesley } & \multicolumn{2}{|c|}{ Ravine } & \multicolumn{2}{|c|}{ Total } \\
\hline & $\mathrm{n}$ & $\%$ & $\mathrm{n}$ & $\%$ & $\mathrm{n}$ & $\%$ & $\mathrm{n}$ & $\%$ \\
\hline \multicolumn{9}{|l|}{ Grade level } \\
\hline 5 th & 16 & 50.0 & 12 & 52.2 & 5 & 21.7 & 33 & 42.3 \\
\hline 6 th & 15 & 46.9 & 10 & 43.5 & 7 & 30.4 & 32 & 41.0 \\
\hline Not reported & 1 & 3.1 & 1 & 4.3 & 11 & 47.8 & 13 & 16.7 \\
\hline \multicolumn{9}{|l|}{ Gender } \\
\hline Female & 13 & 40.6 & 11 & 47.8 & 11 & 47.8 & 35 & 44.9 \\
\hline Male & 19 & 59.4 & 12 & 52.2 & 10 & 43.5 & 41 & 52.6 \\
\hline Not reported & 0 & 0.0 & 0 & 0.0 & 2 & 8.7 & 2 & 2.6 \\
\hline \multicolumn{9}{|l|}{ Ethnicity } \\
\hline Asian & 2 & 6.3 & 0 & 0.0 & 0 & 0.0 & 2 & 2.6 \\
\hline Black/African American & 2 & 6.3 & 1 & 4.3 & 1 & 4.3 & 4 & 5.1 \\
\hline Latino/a & 20 & 62.5 & 8 & 34.8 & 5 & 21.7 & 33 & 42.3 \\
\hline Mixed race & 4 & 12.5 & 8 & 34.8 & 3 & 13.0 & 15 & 19.2 \\
\hline Native American & 0 & 0.0 & 1 & 4.3 & 0 & 0.0 & 1 & 1.3 \\
\hline White & 1 & 3.1 & 0 & 0.0 & 0 & 0.0 & 1 & 1.3 \\
\hline Not reported & 3 & 9.4 & 5 & 21.7 & 14 & 60.9 & 22 & 28.2 \\
\hline
\end{tabular}


ments fully or missed a data collection day. The atrition is discussed further in the discussion section.

\section{Preliminary analyses}

Correlations between the eight variables and reliabilities for scales can be found in Table 3. Cronbach alpha values were acceptable for two of the subscales of scholastic competence, physical appearance competence and parental support. The internal consistency values for self-efficacy and athletic competence were lower with self-efficacy approaching an adequate level (alpha of 0.69 and 0.65 for pre and post respectively). However, caution should be taken when interpreting the findings from these two scales.

\section{Main analyses}

In our analysis, we discovered school differences in post-intervention scores on three out of the eight intervention-related measures. See Table 3 for descriptive statistics for each measure by school and time point (i.e., baseline and post-intervention). We did not find significant differences based on school in the post-intervention scores for physical activity (PAQ-C), $F(2,47)=.81, p=.45$; self-efficacy (PASES), $F(2,48)=2.22, p=.12$; scholastic competence, $F(2,56)=0.29, p=.75$; athletic competence, $F(2,56)=1.21, p=.31$; and physical appearance, $F(2,56)$ $=1.13, p=.33$.

We did find significant differences between schools in the post-intervention measure of parental support while controlling for pre-intervention levels of parental support, $F(2,49)=18.28, p<.01, \eta^{2}=.19$. The eta square effect size indicates $19 \%$ of the difference in post-intervention parental support scores can be attributed to a difference in schools. Based on Gamst et al.'s ${ }^{29}$ guidelines, this is a moderate to strong effect. The post-hoc analyses revealed that for parental support, participants at Riverfront (adjusted $M=3.60, S E=0.17,95 \% \mathrm{CI}=3.26-3.93)$ and at Wesley (adjusted $M=3.86, S E=0.20,95 \% \mathrm{CI}=3.45-$ 4.27) scored significantly higher than participants at Ravine control school (adjusted $M=2.98, S E=0.15,95 \% \mathrm{CI}$ $=2.68-3.27)$. There were no statistically significant group differences in parental support between the two intervention schools: Riverfront and Wesley.

The next significant group difference we found was in the post-intervention reading scores between schools while controlling for pre-intervention scores, $F(2,39)=$ $5.60, p=.01, \eta^{2}=.15$. The eta square effect size indicates a moderate effect ${ }^{29}$ in which $15 \%$ of the variance in post-intervention literacy scores is based on differences between schools. The post-hoc analyses revealed the only significant difference was that post-intervention reading scores at Ravine, the control school (adjusted $M=5.60, S E=0.46$, $95 \%$ CI $=4.66-6.52$ ) were significantly higher than post-intervention reading scores at Riverfront, an intervention school (adjusted $M=2.70, S E=0.81,95 \% \mathrm{CI}=$ $1.07-3.34)$.

While controlling for pre-intervention PACER scores, the final difference between schools was in the post-intervention PACER measure for number of laps run, $F(2,46)$ $=18.29, p<.01, \eta^{2}=.33$. The eta square effect size value shows that the school site explains $33 \%$ of the difference in students' post-intervention PACER scores, which is a strong effect size ${ }^{29}$. Students at Riverfront, an intervention school (adjusted $M=32.36, S E=2.25,95 \% \mathrm{CI}=27.83-$ 36.89) had significantly higher post-intervention PACER scores than students at Ravine, the control school (adjusted $M=20.96, S E=1.88,95 \%$ CI $=17.17-24.76$ ) or Wesley

TABLE 3

INTERCORRELATIONS AND RELIABILITIES FOR STUDY VARIABLES DISAGGREGATED BY TIME

\begin{tabular}{|c|c|c|c|c|c|c|c|c|}
\hline Variable & 1 & 2 & 3 & 4 & 5 & 6 & 7 & 8 \\
\hline 1. PAQ-C & - & $.41^{*}$ & .07 & .16 & -.08 & .18 & -.21 & $.28^{*}$ \\
\hline 2. PASES & .54 & - & .21 & .18 & .08 & .21 & -.12 & .12 \\
\hline 3. SC & .12 & .17 & - & .13 & .12 & .04 & .24 & -.09 \\
\hline 4. $\mathrm{AC}$ & .13 & .19 & .06 & - & .01 & -.06 & -.08 & .17 \\
\hline 5. PAC & -.25 & -.03 & $.38^{*}$ & & - & .13 & .09 & .21 \\
\hline 6. Parental Support & $.51^{*}$ & $.45^{*}$ & .09 & $.28^{*}$ & .01 & - & .06 & .06 \\
\hline 7. Literacy & -.16 & -.10 & .03 & -.21 & -.14 & $-.34^{*}$ & - & -.03 \\
\hline 8. PACER & .24 & $.36^{*}$ & -.02 & .18 & .16 & .19 & -.07 & - \\
\hline $\begin{array}{l}\text { Cronbach's a pre } \\
\text { intervention }\end{array}$ & - & .69 & .70 & .57 & .71 & .71 & - & - \\
\hline $\begin{array}{l}\text { Cronbach's a post } \\
\text { intervention }\end{array}$ & - & .65 & .75 & .56 & .75 & .72 & - & - \\
\hline
\end{tabular}

Note. The results for pre-intervention are shown above the diagonal. The results for post intervention are shown below the diagonal. PAQ-C = Physical Activity for Children Questionnaire; PASES = Physical Activity Self-Efficacy Scale; SC = Scholastic Competence from Harter's Perceived Competence Scale; AC = Athletic Competence from Harter's Perceived Competence Scale; PAC = Physical Appearance from Harter's Perceived Competence Scale; Parental Support = Parental Support for Physical Activity Questionnaire. $* \mathrm{p}<.05$. 
TABLE 4

PRE-INTERVENTION MEANS AND ADJUSTED POST-INTERVENTION MEANS (STANDARD DEVIATIONS) FOR PROGRAM MEASURES

\begin{tabular}{lcccccc}
\hline & \multicolumn{2}{c}{ Riverfront } & \multicolumn{2}{c}{ Wesley } & \multicolumn{2}{c}{ Ravine } \\
\hline Measure & Pre- & Post- & Pre- & Post- & Pre- & Post- \\
\hline PAQ-C & $3.36(0.78)$ & $3.40(0.46)$ & $3.35(0.91)$ & $3.40(0.68)$ & $3.26(0.44)$ & $3.16(0.68)$ \\
PASES & $1.50(0.34)$ & $1.63(0.26)$ & $1.57(0.34)$ & $1.42(0.55)$ & $1.50(0.20)$ & $1.49(0.15)$ \\
SC & $2.62(0.49)$ & $2.72(0.63)$ & $2.85(0.64)$ & $2.78(0.61)$ & $3.06(0.68)$ & $2.86(0.62)$ \\
AC & $2.71(0.42)$ & $2.69(0.61)$ & $2.58(0.59)$ & $2.81(0.61)$ & $2.31(0.76)$ & $2.49(0.63)$ \\
PAC & $2.60(0.75)$ & $2.46(0.64)$ & $2.24(0.47)$ & $2.78(0.67)$ & $2.83(0.75)$ & $2.47(0.65)$ \\
Parental & $3.69(0.84)$ & $3.60(0.68)$ & $2.99(0.98)$ & $3.86(0.74)$ & $3.91(0.41)$ & $2.98(0.71)$ \\
Support & & & & & & \\
Literacy & $2.73(2.40)$ & $2.70(2.14)$ & $1.95(1.83)$ & $4.02(2.28)$ & $3.88(2.03)$ & $5.60(2.19)$ \\
PACER & $26.44(10.07)$ & $32.36(9.28)$ & $21.68(12.90)$ & $9.92(9.19)$ & $22.20(8.51)$ & $20.96(9.04)$ \\
\hline
\end{tabular}

Standard deviations are presented in parentheses. PAQ-C = Physical Activity for Children Questionnaire; PASES = Physical Activity Self-Efficacy Scale; SC = Scholastic Competence from Harter's Perceived Competence Scale; AC = Athletic Competence from Harter's Perceived Competence Scale; PAC = Physical Appearance from Harter's Perceived Competence Scale; Parental Support = Parental Support for Physical Activity Questionnaire.

(adjusted $M=9.92, S E=2.91,95 \% \mathrm{CI}=4.07-15.77$ ) and students at Ravine had significantly higher PACER scores than students at Wesley, an intervention school.

\section{Discussion}

The purpose of this study was to assess the differences in schools with and without the REACH program in terms of PA levels, fitness, perceived competence, self-efficacy, parental support, and literacy outcomes. There were significant results uncovered in cardio-respiratory endurance in intervention schools compared to the control school, yet results from perceived competence questionnaires and other fitness measures showed no significant differences. While there were some differences identified between schools in terms of parental support, literacy and fitness, our results uncover content that we did not expect. The results point less to the validity of an after-school intervention in low SES schools in urban environments. Rather, data, or more notably lack thereof, was a key component to explaining the true effect of this intervention. As we alluded to earlier, we had to discard the mid-year data collection results as there were too many data missing from those measurements. For example, almost half the participants (48.7\%) did not complete the fitness test. During data collection, many students complained about "having to" do yet another test (as they called them). Once students realized that the instruments that we were asking them to fill out did not matter to their grades or have any consequences on them participating in REACH games and activities, the effort quickly subsided. This may be seen in the increase in percent missing from baseline to post in some of the measures such as fitness and questionnaire measures. While some of this missing data may be attributed to absenteeism a large proportion of the missing data was due to students choosing not to fully partic- ipate in the data collection. A more substantial conversation must be had among the research community about the meaningfulness of data collection to the student participants.

The biggest issue in the data collection process was that, although the REACH program itself was designed and delivered as a student-centered program, the data collection process was not meaningful, nor did it engage the participants. This issue was likely exacerbated by the high-stakes testing mandates permeating schools, including the multiple common assessments and baseline measurements administered throughout the year. In the future, data collection techniques could utilize students as data collectors and "junior scientists" who have a stake in collecting accurate, reliable and valid data. This would go beyond youth participatory action research ${ }^{30}$ and push the boundaries of data collection, yet at the same time it may finally allow us to collect reliable and valid data from students in low income and urban schools.

As to the significant results of the current study, we found that perceived parental support was higher for students at both intervention schools than the control school. We began to measure parental involvement at baseline as we hoped to engage parents in a layer of the study. This did not occur as planned. Although our results appear to support our hypothesis, we struggled getting parental involvement in the study and struggled to connect with parents in any meaningful way. For example, we sent out over 100 parent surveys to families participating in the research and even with multiple follow ups, providing translated documents in Spanish, and providing incentives for students to return the parental surveys we only managed to get seven completed surveys. Thus, although results hint at a positive trend of stronger involvement in the intervention schools we did not experience it this way. 
The second significant measurement was the post tests for reading were higher in the control than Riverfront. We believe this finding may point to the lack of control over variability as well as a mismatch between REACH literacy sessions and the reading-centric pre and posttest. Regarding variability, reading instruction and interventions happened at all of these schools throughout the school day. However, with REACH existing as a separate after-school context, we do not know the specificity as to the pedagogical approach for teaching reading in each of these schools. Further, REACH sessions focused broadly on literacy by incorporating reading and writing activities with students' interests guiding students' engagement; however, the pre and posttests aligned with high-stakes testing models.

This misalignment is informing future implementation of literacy in REACH as well as measurements for assessing how student participants' literacy development changes through REACH. Rather than rely on cognitive theories of literacy that take up a simple view of reading ${ }^{31}$, REACH will enhance its literacy components by considering the multiple facets of literacy (reading as well as writing, listening, speaking) and the ways in which these are social $^{32}$, multimodal ${ }^{33}$, embodied ${ }^{34}$, and affectively-charged ${ }^{35,36}$. Likewise, future pre and post assessments will be designed in accordance to more accurately and appropriately reflect how students' experience literacy in REACH.

Finally, we found that Riverfront had higher PACER scores than Ravine (control) which was a welcomed significant result. That said, Ravine, a control school, was higher than Wesley which should for all intents and purposes align with the other intervention school, Riverfront, in increasing PACER scores in order to make any definitive conclusions on the quantitative gains of the REACH program. This was Riverfront's second year with the program and some coaches were there for their second year and a connection to coaches could be a reason we saw more effort at Riverfront.

While this quantitative data suggests limited support for REACH being an effective after-school program, qualitative evidence points to REACH successfully engaging youth in these schools $\mathrm{s}^{19,37-38}$ and others ${ }^{39,40}$. The impetus for this quantitative study was to gather quantitative data that could further explain the potential effects of REACH. We, as researchers, were caught up in trying to quantify something that we "felt was there." In the process, we actually stuffed test after test down to the students who failed to find meaning in any of it. The researchers in this case, forgot who they were there to serve: the students. The REACH curriculum is student-centered and co-created with students and developed and re-developed through feedback from students. The quantitative aspect of this study neglected to seek any feedback from the students who we focused so significantly on within the qualitative aspect of this multi-year project.

In the past few months we have had several meetings to figure out what these data represent for the REACH program. Is it not effective? Did we use too many instru- ments? Are the kids to blame for not following our directions? How can we publish something that doesn't align with what we want to see? Is it ethical to not publish these results at all? All to say, we realized that we missed out on the single reason why we first got into this research: the students. We never sought their input, nor utilized their vast abilities to co-create the data collection methodology for the quantitative instruments. The researchers here lost touch. Approaches to student-centered inquiry as curriculum ${ }^{41}$ or collaborative and participatory approaches such as an activist approach ${ }^{42,43,44}$ could have been useful while collecting the quantitative data. We focused on the sessions and students while we were at the schools and then added data collection methods to try to quantify the impact we were having. In future, we need to re-visit the reason we chose to conduct research in low income urban schools and match that with a holistic student-centered approach that truly connects both all data collection and student experiences in the program.

\section{Limitations}

There are limitations to our study and the reader should consider these limitations when interpreting the data. First, there was a purposeful selection of sites for the intervention. The researchers took REACH into a community of need and to measure the possible effects it had we then decided to conduct a research study. Thus, we are limited to examining a specific low-income community and our results may not be generalizable to other populations. Secondly, we deliberately choose not to conduct measurements via accelerometry. The reason for this was that there was an overwhelming amount of missing data from the year prior during the 2016-2017 intervention that led to a large amount of lost and missing accelerometers and very low compliance in wear time ${ }^{37}$. Students in the community did not respond well to accelerometers so we chose to not use them again to conduct data collection. Some of the valid and reliable instruments also relied on student recall and results should be interpreted with that in mind. Finally, there was a notable attrition in the upper classes from baseline to post. This was due to parents allowing students to sign themselves out of the after-school program which was an unexpected event. Thus, some students who began the study did not finish the study and therefore we cannot examine a pre/post effect.

\section{Conclusion}

This study uncovered significant methodological issues that should be considered when conducting research with urban low-income schools during after-school programs. Future research should examine best practices in gathering data with youth and parents in low-income communities. The missing data we were faced with were still present even though best practices were employed from previous research. Methods to working with youth to gather valid and reliable results during PA interventions should be revisited. 


\section{R E F E R E N C E S}

1. PARSAD B, LEWIS L, After-school programs in public elementary schools (U.S. Department of Education. Washington, DC, 2009). - 2 . WEISMAN SA, WOMER SC, KELLSTROM M, BRYNER S, KAHLER A, SLOCUM LA, Maryland after school grant program part 1: Report on the 2001-2002 school year evaluation of the phase 3 after school programs (Unpublished manuscript, University of Maryland, 2003). - 3. WELSH ME, RUSSELL CA, WILLIAMS I, REISNER ER, WHITE RN, Promoting learning and school attendance through after-school programs: Student-level changes in educational performance across TASC's first three years (Policy Studies, Washington DC, 2002). - 4. DYNARSKI M, JAMES-BURDUMY S, MOORE M, ROSENBERG L, DEKE J, MANSFIELD W, When schools stay open late: The national evaluation of the 21st century community learning centers program--New findings. (US Department of Education, Washington DC, 2004). - 5. LAUER PA, AKIBA M, WILKERSON SB, APTHORP HS, SNOW D, MARTINGLENNML, RevEducRes, 76(2006) 275. doi:10.3102/00346543076002275. - 6. AFTERSCHOOL ALLIANCE, America after 3PM: Afterschool programs in demand, 2014, http://afterschoolalliance.org/documents/ AA3PM-2014/AA3PM_National_Report.pdf. - 7. BASCH CE, J School Health, 81 (2011) 626. doi:10.1111/j.1746-1561.2011.00637.x. - 8. STALSBERG R, PEDERSEN AV, Scand J Med Sci Sports, 20 (2010) 368. doi:10.1111/j.1600-0838.2009.01047.x. - 9. BRODERSEN NH, STEPTOE A, BONIFACE DR, WARDLE J, Br J Sports Med, 41 (2007) 140. doi:10.1136/bjsm.2006.031138. - 10. SHEPARD RJ, LAVALLEE H, VOLLE M, LABARRE R, BEAUCAGE C, CAHPER Research Supplement, 1 (1994) 1. - 11. COE DP, PIVARNIK JM, WOMACK CJ, REEVES MJ, MALINA RM, Med Sci Sports Exerc, 38 (2006) 1515. doi:10.1249/01. mss.0000227537.13175.1b. - 12. RASBERRY CN, LEE SM, ROBIN L, LARIS BA, RUSSELL LA, COYLE KK, NIHISER AJ, Prev Med, 52 (2011) S10. doi:10.1016/j.ypmed.2011.01.027. — 13. RAUDSEPP L, LIBLIK R, HANNUS A, Pediatr Exerc Sci, 14 (2002) 97. doi:10.1123/ pes.14.1.97. - 14. CROCKER PR, EKLUND RC, KOWALSKI KC, J Sports Sci, 18 (2000) 383. doi:10.1080/02640410050074313. - 15. SALLIS JF, PROCHASKA JJ, TAYLOR WC, Med Sci Sports Exerc, 32 (2000) 963. doi:10.1097/00005768-200005000-00014. — 16. BARNETT LM, MORGAN PJ, VAN BEURDEN E, BEARD JR, Int J Behav Nutr Phys Act, 5 (2008) 40. doi:10.1186/1479-5868-5-40. — 17. GUSTAFSON SL, RHODES RE, Sports Med, 36 (2006) 79. doi:10.2165/00007256200636010-00006. - 18. XU H, WEN LM, RISSEL C, J Obes, 2015 (2015) 1. doi: 10.1155/2015/546925. - 19. MARTTINEN R, FREDRICK R, JOHNSTON K, PHILLIPS S, PATTERSON D, European Physical Education Review 26 (2020) 410. doi:10.1177/1356336X19865566. - 20. MARTTINEN R, JOHNSTON K, PHILLIPS S, FREDRICK RN, MEZA B, Physical Education and Sport Pedagogy, 24/4 (2019) 373. doi:10.1080/ 17408989.2019.1592147. — 21. SPIELBERGER J, HALPERN R, The role of after-school programs in children's literacy development (Chapin Hall Center for Children at the University of Chicago, Chicago, 2002). - 22 . KOWALSKI KC, CROCKER PRE, DONEN RM, The physical activity questionnaire for older children (PAQ-C) and adolescents (PAQ-A) manual (College of Kinesiology, University of Saskatchewan, Saskatoon,
2004). http://www. dapa-toolkit. mrc. ac. uk/documents/en/PAQ/PAQ_ manual.pdf. - 23. PLOWMAN SA, Muscular strength, endurance, and flexibility assessments. In: Fitnessgram/Activitygram Reference Guide (Internet Resource, The Cooper Institute, Dallas, 2013). - 24. BARTHOLOMEW JB, LOUKAS A, JOWERS EM, ALLUA S, J Phys Act Health, 3 (2006) 70. doi:10.1123/jpah.3.1.70. - 25. HARTER S, The relationship between perceived competence, affect, and motivational orientation within the classroom: Processes and patterns of change. In: BOGGIANO AK, PITTMAN TS (Eds): Achievement and motivation: A social-developmental perspective (Cambridge University Press, Cambridge, 1992). - 26. HARTER S, Self-perception profile for adolescents: Manual and questionnaires (University of Denver, Denver, 2012). - 27. TROST SG, SALLIS JF, PATE RR, FREEDSON PS, TAYLOR WC, DOWDA M, Am J Prev Med, 25 (2003) 277. doi:10.1016/S0749. 3797(03)00217-4. - 28. SMARTER BALANCED ASSESSMENT CON SORTIUM, Chapter 1: Validity In: Smarter Balanced 2014-15 Technical Report (Los Angeles, 2015). https://portal.smarterbalanced.org/library/ en/2014-15-technical-report.pdf. - 29. GAMST G, MEYERS LS, GUARINO AJ, Analysis of variance designs: A conceptual and computational approach with SPSS and SAS (Cambridge University Press, Cambridge, 2008). - 30. CAMMAROTA J, FINE M, Revolutionizing education: Youth participatory action research in motion (Routledge, New York, 2010) 31. GOUGH PB, HOOVER WA, PETERSON CL, Some observations on a simple view of reacting. In: CORNOLDI C, OAKHILL JV (Eds): Reading comprehension difficulties: Processes and intervention (Rout ledge, New York, 2013). doi:10.4324/9780203053324. — 32. STREET B, Curr. Issues Educ, 5 (2003) 77. — 33. SIEGEL M, Lang Arts, 84 (2006) 65. - 34. ENRIQUEZ G, JOHNSON E, KONTOVOURKI S, MALLOZZI CA (Eds) Literacies, learning, and the body: Putting theory and research into pedagogical practice (Routledge, New York, 2015). - 35. MARTTINEN R, SIMON M, PHILLIPS S, FREDRICK III RN, Journal of Teaching in Physical Education, 40 (2020) 1. doi:10.1123/jtpe.2019-0211. - 36. LEANDER K, BOLDT G, J Lit Res, 45 (2013) 22. doi:10.1177/1086296X12468587. - 37. MEZA B, MARTTINEN R, Journal of Youth Development 14/4 (2019) 216. doi:10.5195/jyd.2019.771. — 38. MARTTINEN R, JOHNSTON K, FLORY SB, MEZA B, Physical Education and Sport Pedagogy, 25/6 (2020) 585. doi:10.1080/17408989.2020.17 61954. - 39. Johnston KC, Marttinen R, Frederick RN, Bhat VR, Journal of Youth Development 14 (2019) 93. doi:10.5195/jyd.2019.729. — 40. Marttinen R, Landi D, Novak D, Silverman S, Review of Research on Teaching in Physical Education: Two Decades of Progress. AERA Online Paper Repository. (Paper presented at the Annual Meeting of the American Educational Research Association Toronto, Canada, Apr 5-9, 2019). doi:10.302/1438812. — 41. OLIVER KL, OESTERREICH HA, J Curric Stud, 45 (2013) 394. doi:10.1080/00220272.2012.719550. 42. OLIVER KL, KIRK D, Phys Educ Sport Pedagogy, 21 (2016) 327. doi:10.1080/174 08989.2014.895803. - 43. NUÑEZ ENRIQUEZ O, OLIVER, KL, Sport Educ Soc, 26 (2021) 459. doi:10.1080/13573322.2020.1738374 - 44. LUGUETTI C, OLIVER KL, The Curr J 32 (2021) 118. doi:10.1002/curj.81.

\section{R. Marttinen}

George Mason University, 4400 University Drive, Fairfax, Virginia 22030

e-mail:rmarttin@gmu.edu 


\section{TJELESNA SPREMNOST, TJELESNA AKTIVNOST, PERCIPIRANA KOMPETENCIJA, PODRŠKA RODITELJA I REZULTATI PISMENOSTI U REACH-OVOM SPORTSKOM PROGRAMU POSLIJE SKOLE}

\section{S A Ž E T A K}

Svrha ove studije bila je procijeniti učinkovitost REACH programa u povećanju razine tjelesne aktivnosti (TA), kardiorespiratorne kondicije, percipirane kompetencije, samoučinkovitosti, roditeljske podrške i pismenosti tijekom jednogodišnje intervencije TA nakon škole. Dvije intervencijske i jedna kontrolna škola ( $N=78$ učenika) angažirane su za prikupljanje podataka u dvije vremenske točke. Razlike u rezultatima nakon intervencije pronađene su u tri (roditeljska podrška, pismenost, PACER) od sedam mjera povezanih s intervencijom. Roditeljska podrška i PACER rezultati bili su viši u intervencijskim školama. Rezultati pokazuju da je potrebno preispitati metode prikupljanja podataka u školama koje polaze djeca roditelja s niskim primanjima. Predstavljen je problem oko prikupljanja podataka; istraživačima su nužni podatci kako bi razumjeli što se događa u praksi, ali što samo prikupljanje podataka pruža djeci i mladima? Potrebno je razmotriti nove pristupe u urbanim programima poslije škole koje polaze djeca roditelja s niskim primanjima kako bi se ograničio gubitak podataka i kako bi prikupljanje podataka bilo smisleno za učenike. 